\title{
INFLUENCE OF SURFACE PRE-HEATING ON THE NITRIDING DEPTH OF STEEL 25CrMOVA USED COMPLEX ION-PLASMA TREATMENT
}

\author{
V.A. Belous, Yu.A. Zadneprovskiy, I.S. Domnich \\ National Science Center "Kharkov Institute of Physics and Technology", \\ Kharkiv, Ukraine \\ E-mail: yaz@kipt.kharkov.ua
}

In the method of nitriding elements, various methods of their thermal heating are used. The simplest heating method in ion-plasma nitriding is heating by bombarding the surface first with low-energy gas ions and then with metal ions with energies up to several kiloelectronvolt. Elements exposed to ion bombardment have a welldeveloped surface that is free from contaminants and facilitates the diffusion of nitrogen into the depth of the metal during nitriding. The paper studies the effect of various preliminary heating methods on the nitriding depth in the complex ion-plasma hardening technology of 25CrMoVA steel. A JSM 7000-1F scanning electron microscope equipped with an X-ray spectral energy dispersive microanalysis attachment was used to diagnose changes occurring on the surface of the samples and at depth; the hardness was measured using a Nanoindentor G200 device. The preliminary heating of the samples was carried out both with the use of bombardment with Ti or Mo ions, and without its direct effect on the heated surface. In the experiment, differences in the depth of hardening of the nitrided layer of steel are observed when it is heated in different ways. When bombarded with Mo ions, the greatest depths of hardening were obtained in comparison with other preliminary heating conditions. It is shown that these differences are associated with the features of the morphology of the steel surface formed as a result of sputtering processes. The formation of nitride compounds in its surface layer can serve as a barrier that slows down the penetration of nitrogen into the metal. It is shown that with complex treatment in the process of deposition of a nitride coating on the surface of nitrided steel, an additional increase in the depth of hardening of the nitrided layer occurs.

\section{INTRODUCTION}

The technology of complex ion-plasma hardening consists of several stages of surface modification in order to increase the protective characteristics of elements $[1,2]$. Complex ion-plasma hardening of the surface, including the stages of ion-plasma nitriding (IPN) and deposition of vacuum-arc coatings, provides a fairly thick $(100 \ldots 300 \mu \mathrm{m})$ hardened layer of steel, as well as a nitride coating that increases its surface wear resistance [3]. Such complex treatment is used, in particular, to increase the strength, erosion-resistant and other service characteristics of the working surfaces of the elements of the steam distribution and turbine control mechanisms in order to increase their resource [4].

With IPN, used in complex technology, obtaining large depths of hardening (up to $300 \mu \mathrm{m}$ ), which, as a rule, are consistent with the depths of nitrogen penetration [4], is quite a feasible task. In comparison with traditional "furnace" nitriding, the IPN process is more efficient. The high performance of such nitriding is due to the special state of nitrogen, prepared before it penetrates into the steel. Thus, in the atmosphere of a gas two-stage vacuum-arc discharge [5], activated nitrogen is used, which is in an ionized and excited state. The rather high energy of diffusing nitrogen ions (up to $\sim 0.8 \mathrm{keV}$ ), in this case, determines the accelerating voltage applied to the product. The described IPN conditions are decisive for the occurrence of more efficient high-speed processes of surface saturation.

In addition, with IPN the process of nitriding the surfaces of the element takes place not under atmospheric conditions, as is the case in the case of "furnace" nitriding, but under conditions of high $\left(5 \cdot 10^{-3} \ldots 5 \cdot 10^{-4}\right.$ Torr $)$ vacuum. This factor practically excludes the formation of oxides and other "random" compounds with iron and other steel alloying metals during processing. Thus, conditions are created on the surface modified by IPN for obtaining good adhesion with the protective nitride coating deposited in the complex technology.

During the IPN process, the main energy costs are associated with heating the element to the optimal temperature. The simplest way to achieve this heating is to use preliminary ion bombardment, first with lowenergy gas ions and then with metal ions with energies up to several kiloelectronvolt. The influence of ion bombardment on the morphology of the steel surface, as well as the influence of the latter on the increase in nitriding depths, has been little studied.

The aim of this work is to study the influence of various methods of preliminary heating of elements on the depth of nitriding with a complex ion-plasma hardening technology.

\section{MATERIALS AND METHODS OF RESEARCH}

The "Support" element was chosen as a model for the experiments, which is operated in the friction pair of the steam distribution mechanism of the K-325 turbine [4].

The element is made of heat-resistant steel 25CrMoVA. The chemical composition of steel according to State Standard No. 20072-74 is presented in Table 1 . 
Table 1

Chemical composition of steel 25CrMoVA in mass

\begin{tabular}{|c|c|c|c|c|c|c|c|c|c|}
\hline $\mathrm{C}$ & $\mathrm{Si}$ & $\mathrm{Mn}$ & $\mathrm{Ni}$ & $\mathrm{S}$ & $\mathrm{P}$ & $\mathrm{Cr}$ & $\mathrm{Mo}$ & $\mathrm{V}$ & $\mathrm{Cu}$ \\
\hline $0.22 \ldots 0.29$ & $0.17 \ldots 0.37$ & $0.4 \ldots 0.7$ & $\begin{array}{c}\text { up to } \\
0.3\end{array}$ & $\begin{array}{c}\text { up to } \\
0.025\end{array}$ & $\begin{array}{c}\text { up to } \\
0.03\end{array}$ & $1.5 \ldots 1.8$ & $0.6 \ldots 0.8$ & $0.15 \ldots 0.3$ & up to 0.2 \\
\hline
\end{tabular}

Some difficulties for the processes of ion-plasma modification may arise due to the massiveness of this element due to the need to achieve the required temperature level (up to $600{ }^{\circ} \mathrm{C}$ ) during hardening. The element weight was $\sim 6 \mathrm{~kg}$. The study of the processes of ion-plasma modification was carried out using local samples fixed in the body of a massive model of the element called "Support" (Fig. 1) (hereinafter referred to as model). Samples with a size of 20x10x6 mm were tightly fixed in the grooves made in the body of the model, and their surfaces, on which the coatings were deposited, were flush with the surface of the model. This ensured that the temperatures of the samples and the model of the element were consistent.

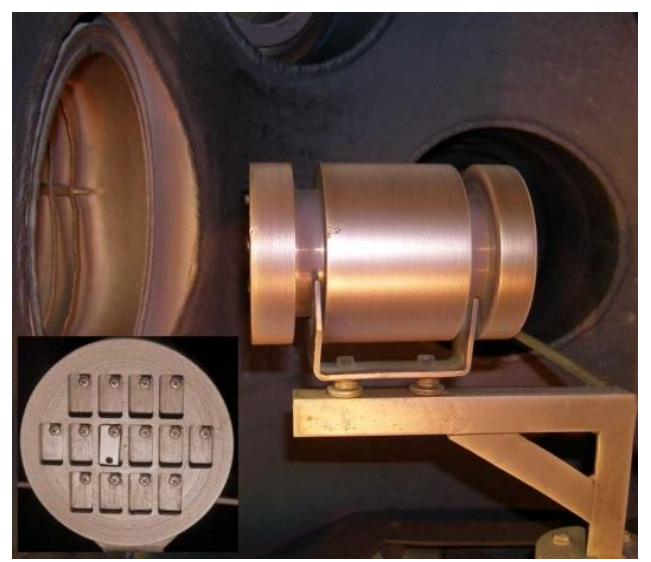

Fig. 1. Images of the model of the element on the substrate holder and samples at its end

To measure the hardness and thickness of the hardened layers, a Nanoindentor G200 was used, while the thickness of the nitriding hardened layer was determined from metallographic sections. The indentation was carried out in a step-by-step mode with an interval of $10 \mu \mathrm{m}$ at a nanoindentor penetration depth of $500 \mathrm{~nm}$. With these parameters of nanoindentation, the surface hardness of 25CrMoVA steel samples was measured, which was $\sim 4 \mathrm{GPa}$.

The study of the morphology of the surface of steel samples modified under various conditions by ionplasma treatment, as well as its elemental composition, was carried out on a JSM 7000-1F scanning electron microscope (SEM) equipped with an X-ray spectral device. The study of the phase composition of the modified surface was carried out on a X-ray diffractometer in cobalt $\mathrm{Co}-\mathrm{K} \alpha$ radiation using a $\mathrm{Fe}$ selectively absorbing filter. Diffracted radiation was detected by a scintillation detector. Quantitative phase analysis and determination of the phase lattice parameters were carried out using the Rietveld method.

The process of complex ion-plasma hardening of samples from steel 25CrMoVA consisted of several technological stages:
1 - heating the model of the element to the nitriding temperature $\left(\leq 600{ }^{\circ} \mathrm{C}\right)$ under various conditions of ionplasma treatment of the surface of the samples;

2 - IPN of samples. Potential applied to the substrate, $\mathrm{U}_{\text {bias }}=-600 \mathrm{~V}$;

3 - deposition of vacuum-arc coating $\mathrm{Mo}_{2} \mathrm{~N}$.

As alternative methods of preparing the model before nitriding, the following were used: heating by bombarding the surface with metal ions and indirect heating without modifying the surface of the samples ("thermal heating").

To heat the surface by ion bombardment, we used Mo or $\mathrm{Ti}$ ions accelerated by the potential $\mathrm{U}_{\text {bias }}=$ $-1.2 \mathrm{kV}$

During "thermal heating", the model of the element was heated by ion bombardment to the operating temperature of nitriding without the direct effect of accelerated ions on the surface of the sample. For this, for the heating period, the surface of the sample, fixed in the groove of the model, was screened with a shutter, which was opened during the nitriding process. Thus, the sample surface was not exposed to ion sputtering and was in the input polishing state. Heating of the samples located behind the shutter, as well as samples treated by different types of ions ( $\mathrm{Ti}$ and $\mathrm{Mo}$ ), was carried out to the same nitriding temperature.

Unspecified processing modes of steel samples at the stages of IPN and deposition of a vacuum-arc coating in all experiments were maintained the same.

\section{RESULTS AND ITS DISCUSSION}

The view of the input (untreated) surface of the 25CrMoVA steel sample is presented in Fig. 2.

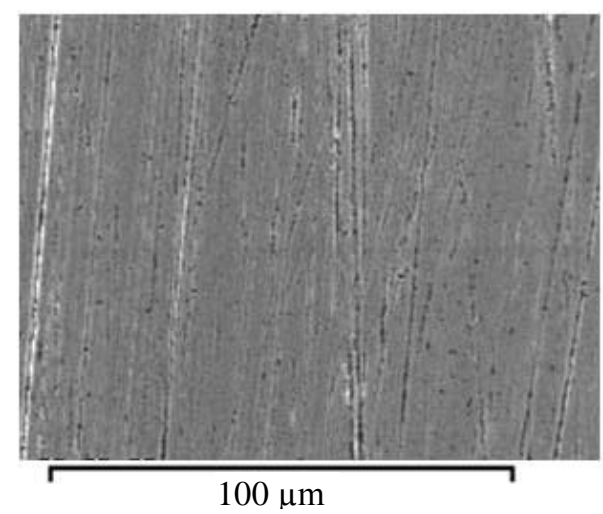

Fig. 2. SEM image of the surface of a 25CrMoVA steel sample

Grinding marks are visible on the sample surface shown in this figure. The value of the roughness parameter $\mathrm{Ra}$ (the arithmetic mean deviation of the profile) of the original surface does not exceed $0.8 \mu \mathrm{m}$, which corresponds to the 7 th class of cleanliness.

The conditions influencing the increase in the depth of the layer hardened by nitriding may include various methods of ion-plasma preparation of the model used to 
heat it before the nitriding process. As noted above, Mo and $\mathrm{Ti}$ ions were used to heat the surfaces of the model and samples by bombardment. Fig. 3 shows images of the surface of steel samples after bombardment with Mo and $\mathrm{Ti}$ ions accelerated by the potential $\mathrm{U}_{\text {bias }}=-1.2 \mathrm{kV}$.

It can be seen from the figure that on the surface of the samples treated with these ions, no scratches are observed that remained after grinding (see Fig. 2). At the same time, the structure of the surfaces shown in Fig. 3 (1) and (2) is noticeably different from each other. On the surface treated with Mo ions (see Fig. 3 (2)), one can see structural formations with a closed complex contour, inside which substructure elements are present. Their size and shape correlate with the size and shape of grains of steel. In contrast to the surface treated with Mo ions, after bombardment with Ti ions (see Fig. 3 (1)), a smoother steel surface is observed and with formations of a different nature not related to the shape and size of the grains. The elements of the substructure are absent.
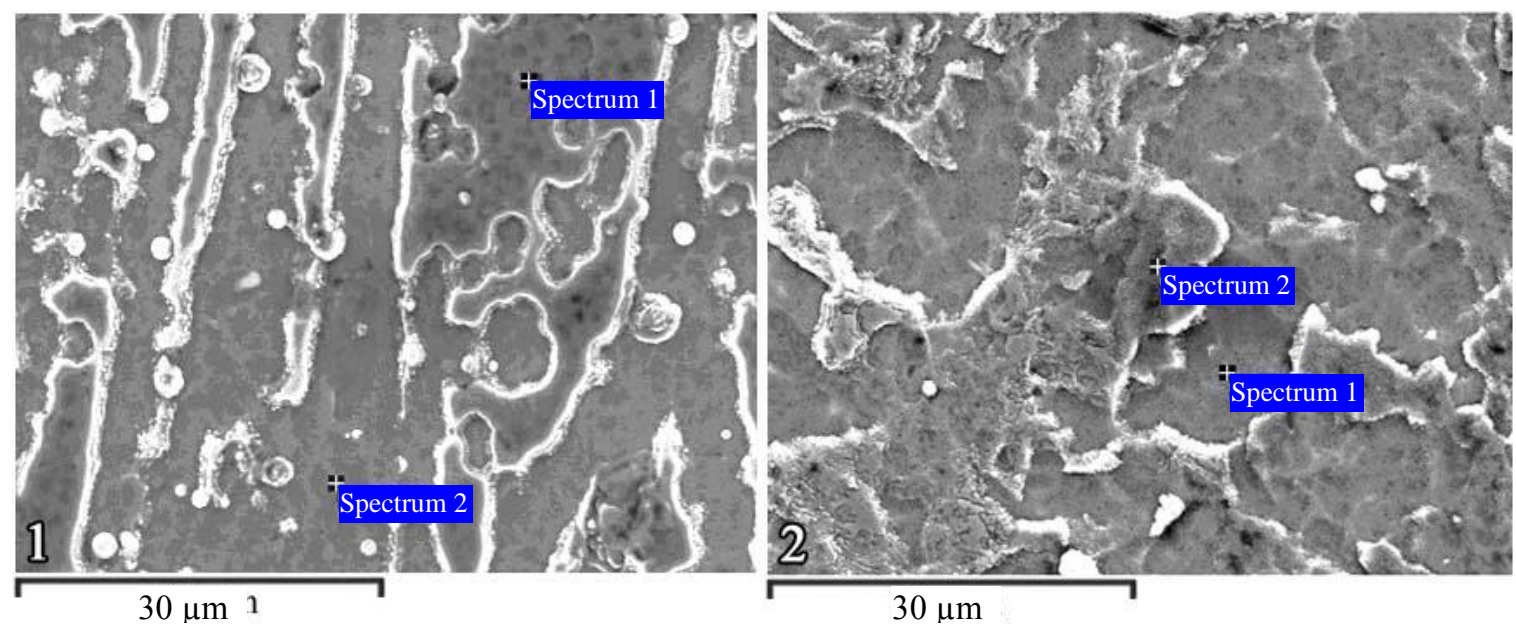

Fig. 3. Surface morphology of samples treated with Ti (1) and Mo (2) ions, indicating the locations of elemental analysis

Thus from the above, we can conclude that the considered in Figs. 2 and 3 the differences in surface morphology are associated with the different sputtering ability of the bombarding ions used.

To explain these differences, their elemental composition was determined in typical regions the measurement locations of which are indicated in the images in Fig. 3. Measurements of the elemental composition of the surface of the samples were carried out without taking into account the carbon content in the steel and the results are presented in Table 2.

Table 2

Comparative elemental composition of the surface of the input steel samples and steel samples treated with Mo and Ti ions

\begin{tabular}{|c|c|c|c|c|c|}
\hline \multirow{3}{*}{ Component } & \multicolumn{5}{|c|}{ Composition, at.\% } \\
\cline { 2 - 6 } & \multirow{3}{*}{ Input surface } & \multicolumn{2}{|c|}{ Mo bombardment } & \multicolumn{2}{c|}{ Ti bombardment } \\
\cline { 3 - 6 } & & spectrum 1 & spectrum 2 & spectrum 1 & spectrum 2 \\
\hline $\mathrm{Si}$ & 0.92 & 0.76 & 0.74 & 0.99 & 0.49 \\
\hline $\mathrm{V}$ & 0.81 & - & - & - & - \\
\hline $\mathrm{Ti}$ & - & - & - & 4.03 & 0.79 \\
\hline $\mathrm{Cr}$ & 1.36 & 1.88 & 2.11 & 2.09 & 2.75 \\
\hline $\mathrm{Mn}$ & 0.47 & 0.60 & 0.68 & 0.70 & 0.59 \\
\hline $\mathrm{Fe}$ & 95.25 & 95.62 & 94.91 & 91.81 & 95.08 \\
\hline $\mathrm{Ni}$ & 0.23 & 0.21 & 0.25 & 0.18 & 0.11 \\
\hline $\mathrm{Mo}$ & 0.96 & 0.93 & 1.31 & 0.19 & 0.18 \\
\hline $\mathrm{Total}$ & 100.00 & 100.00 & 100.00 & 100.00 & 100.00 \\
\hline
\end{tabular}

Comparison of the data given in the Table 2 indicates the formation of a Ti film on the steel surface, and titanium is not uniformly distributed on it. When the surface is bombarded with Mo ions the input composition of the steel practically does not change.

Thus when the surface is bombarded with $\mathrm{Ti}$ ions under the experimental conditions, where the model was heated to the nitriding temperature, a non-continuous $\mathrm{Ti}$ film was formed.

In Fig. 4 shows the images of the surfaces of samples heated in different ways, which were obtained before and after the IPN process when scanning on an SEM at an angle of $40^{\circ}$ to their surface. 

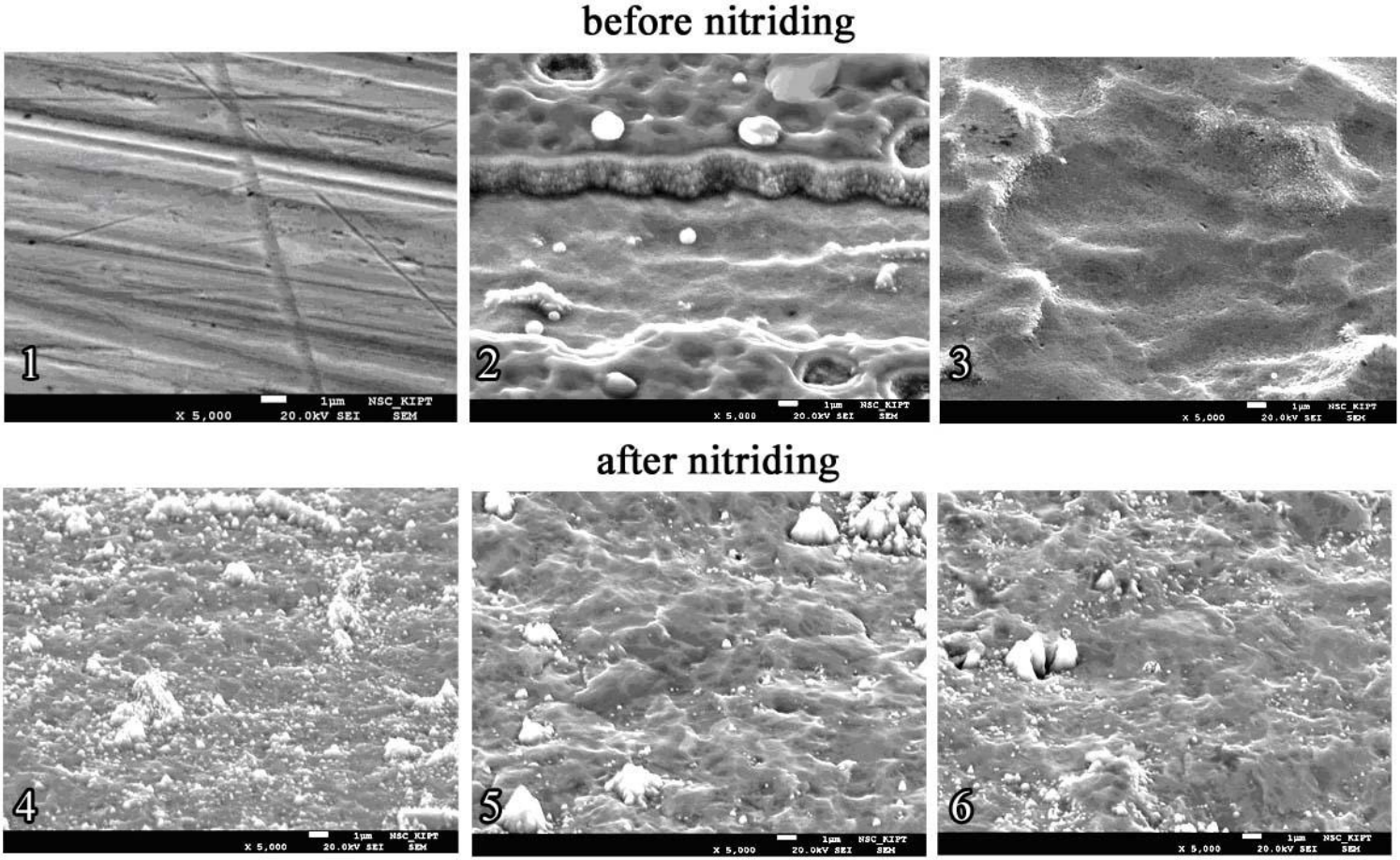

thermal heating

heating by Ti ions

heating by Mo ions

Fig. 4. Surface morphology of steel samples heated in different ways: behind the shutter (1, 4), bombardment with Ti ions (2, 5), and Mo ions (3, 6). Magnification x 5000

The differences observed in images 1,2 , and 3 (see Fig. 4) indicate a different degree of development of the steel surface relief. The most developed is the surface sputtered with Mo ions (see Fig. 4 (3)). At the same time, in Fig. 4 (2) a stair is observed between the surfaces of the steel and the formed film. As seen at the face plane it has a nano-sized granular structure. The thickness of this film is about $1 \mu \mathrm{m}$. Such a modified layer can be formed during ion bombardment as a result of the processes of sputtering and mixing of bombarding ions with the substrate material. The sputtering ability of Mo ions is higher than that of Ti ions due to their higher kinetic energy $\left(\mathrm{E}_{\mathrm{o}}=58.9 \mathrm{eV}\right.$ against $\left.149 \mathrm{eV}[6]\right)$, acquired when leaving the cathode spot, and due to the higher average charge of these ions $(\mathrm{z}=3.1$ against 2.1 [6]). According to the formula $E_{i}=z e U$, the energies of these ions $E_{i}$ increase in the Debye layer near the sputtered surface, to which a negative potential $\mathrm{U}_{\text {bias }}=$ $-1.2 \mathrm{kV}$ was applied.

Thus, the ion bombardment of the surface by a flow of lower-energy Ti ions, in comparison with the flow of higher-energy Mo ions, is characterized by a lower efficiency of self-sputtering processes; therefore, part of the titanium during ion mixing takes part in the formation of the surface film.

It should be noted that, after nitriding, microroughnesses on the surface of samples heated by various methods (see Fig. 4 (4-6)) are smoothed out (the development of the relief decreases). The leaving of the microroughness profile also occurs due to the action of the sputtering and ionic mixing processes, since during the IPN process, a high negative potential $(-600 \mathrm{~V})$ is applied to the substrate.
Fig. 5 shows the results of measuring the hardness in depth from the surface for three samples, nitrided under the same conditions of this process, but under different conditions of preliminary heating.

It can be seen from the graph that all samples in the near-surface region $(0 \ldots 50 \mu \mathrm{m})$ have the hardness of nitrided steel $(8 \ldots 10 \mathrm{GPa})$, which at a distance of more than $90 \mu \mathrm{m}$ from the surface decreases exponentially and at a distance of more than $200 \mu \mathrm{m}$ corresponds to the level of hardness of the input steel $(\sim 4.5 \mathrm{GPa})$. The sloped sections of curves 1 and 2 are superimposed on each other, which indicate the same depths of hardening of steel samples when using preliminary thermal heating and heating with Ti ions.

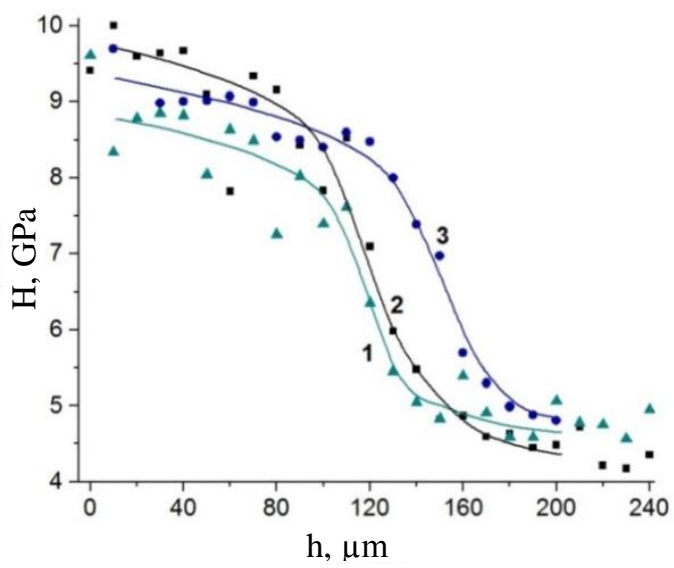

Fig. 5. Profiles of hardness in depth in ion nitriding processes: 1 -after heating with Ti ions;

2 - after thermal heating;

3 - after heating with Mo ions 
The inclined curve piece 3 is located to the right at $35 \ldots 40 \mu \mathrm{m}$, which indicates greater (by $\sim 30 \%$ ) depths of hardening of the nitrided sample irradiated with Mo ions as compared to other preliminary heating conditions. It was shown in [4] that the behavior of the hardness curves depending on the nitriding depth correlates with the course of the curves demonstrating the distribution of the nitrogen concentration incorporated into the steel.

Fig. 6 shows the results of the distribution of hardness in depth from the surface for samples that underwent complex treatment with the deposition of a $\mathrm{Mo}_{2} \mathrm{~N}$ coating upon preliminary heating with $\mathrm{Ti}$ and $\mathrm{Mo}$ ions.

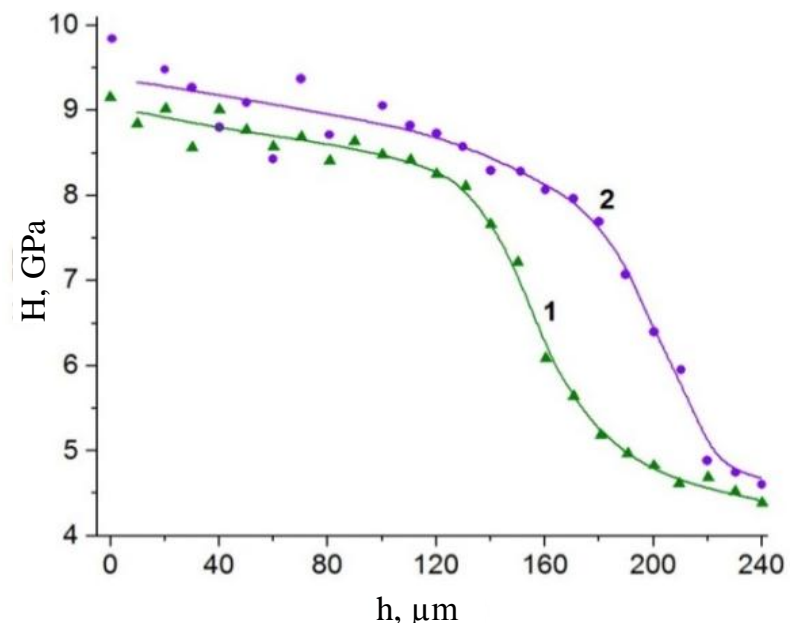

Fig. 6. Profiles of hardness in depth in complex processes after preliminary heating: 1 - Ti ions; 2 - Mo ions

Fig. 6 shows that the depth of samples hardening in the complex process after preliminary heating of the surface with Mo ions is greater than after heating with Ti ions. This result is in full agreement with the result obtained on the samples after nitriding (see Fig. 5). When comparing the results shown in Figs. 5 and 6 it also follows that in the process of complex processing at the stage of deposition of the nitride coating, an additional increase in the depth of hardening of the nitrided layer occurs. As shown [7], this effect is realized due to the processes of nitrogen redistribution from the surface of nitrided steel into its depth.

Thus, in order to obtain the greatest depths of hardening as a result of complex ion-plasma treatment, all other conditions being equal, for preliminary heating of the surface, it is advisable to use bombardment with heavy metal ions, for example, molybdenum ions.

Ion-plasma treatment processes are characterized by certain disequilibrium energy impact on a surface and may lead, particularly when using heavy ions Mo, a sufficiently large temperature gradient between the modifiable surface and subsurface layers of steel. Such an impact can affect the phase changes of the surface layer, which, in turn, determines the efficiency of the nitriding process.

For this aim, the phase composition of steel samples irradiated with different ions, as well as nitrided samples previously prepared by these various surface treatments, was studied, for which the method of X-ray structural analysis was used.

In these studies, it was shown that on the surface of nitrided samples of steel 25CrMoVA, in comparison with non-nitrided samples, the $\alpha-F e$ lines are significantly weakened and shifted towards smaller angles, which indicates an increase in the lattice period associated with the formation of a solid solution of nitrogen in the iron lattice.

Table 3

Phase composition of the surface of the studied samples

\begin{tabular}{|c|c|c|c|}
\hline $\begin{array}{c}\text { Sample } \\
\text { No. }\end{array}$ & Treatment type & Phase & $\begin{array}{c}\text { Weight, } \\
\text { wt.\% }\end{array}$ \\
\hline 1 & $\begin{array}{l}\text { Without } \\
\text { treatment }\end{array}$ & $\alpha-\mathrm{Fe}$ & 100 \\
\hline \multirow{3}{*}{2} & \multirow{3}{*}{$\begin{array}{l}\text { Thermal heating } \\
\text { + nitriding }\end{array}$} & $\alpha-\mathrm{Fe}$ & 45.1 \\
\hline & & $\mathrm{Fe}_{3} \mathrm{~N}$ & 7.5 \\
\hline & & $\mathrm{Fe}_{4} \mathrm{~N}$ & 47.4 \\
\hline \multirow{2}{*}{3} & \multirow{2}{*}{ Ti bombardment } & $\alpha-\mathrm{Fe}$ & - \\
\hline & & $\alpha-\mathbf{T i}$ & - \\
\hline \multirow{3}{*}{4} & \multirow{3}{*}{$\begin{array}{l}\text { Ti bombardment } \\
\text { + nitriding }\end{array}$} & $\alpha-\mathrm{Fe}$ & 47.9 \\
\hline & & $\mathrm{Fe}_{3} \mathrm{~N}$ & 31.9 \\
\hline & & $\mathrm{Fe}_{4} \mathbf{N}$ & 20.2 \\
\hline 5 & Mo bombardment & $\alpha-\mathrm{Fe}$ & 100 \\
\hline \multirow{3}{*}{6} & \multirow{3}{*}{$\begin{array}{l}\text { Mo bombardment } \\
+ \text { nitriding }\end{array}$} & $\alpha-\mathrm{Fe}$ & 47.8 \\
\hline & & $\mathrm{Fe}_{3} \mathrm{~N}$ & 10.0 \\
\hline & & $\mathrm{Fe}_{4} \mathrm{~N}$ & 42.2 \\
\hline
\end{tabular}

The results X-ray structural studies of the phase composition are presented in Table 3 . It can be seen from these data that the formation of the $\alpha$-Ti phase is observed on the surface of the sample, preliminary bombarded with titanium ions (sample No. 3). This confirms the conclusion about the formation of a $\mathrm{Ti}$ film, already drawn from the results of the elemental analysis of the surface of steel samples treated with Mo and $\mathrm{Ti}$ ions (see Table 2). The determination of the quantitative content of the $\alpha$-Ti phase by the X-ray structural method is difficult due to the low concentration of titanium in the film formed on the steel surface.

At the same time, from Table 3, it follows that the iron nitride $\mathrm{Fe}_{4} \mathrm{~N}$ phase is predominantly formed on the nitrided surface pretreated with Mo ions (sample No. 6), while on the nitrided surface treated with $\mathrm{Ti}$ ions (sample No. 4), on the contrary, a higher content of the $\mathrm{Fe}_{3} \mathrm{~N}$ phase is observed, which is more nitrogenated than the first. That is, the presence of a titanium film on the surface before nitriding leads to the formation of nitride phases with higher nitrogen content on the nitrided surface. Apparently, the formation of such phases is activated by titanium, for which nitrogen has a high affinity. Table 3 also shows that the phase composition of nitrided surfaces both thermally heated (sample No. 2) and treated with Mo ions (sample No. 6) is practically the same.

Thus, the presence of titanium on the surface during nitriding leads to the formation of lower iron nitrides, while nitrogen is "retained" in the near-surface layers of steel and, on the contrary, a "clean" developed surface 
sputtered with Mo ions increases the efficiency of diffusion penetration of nitrogen into the depth of the steel which leads to an increase in the depth of hardening of the nitrided layer. In this case, the formation of other nitride compounds of metals alloying steel is quite possible in the near-surface layers. The formation of nitride compounds can be confirmed by the fact that after nitriding such a sample acquires the color of $\mathrm{Ti}_{\mathrm{x}} \mathrm{N}$ compounds. In this case, a nitride layer forms on the surface, which is a barrier to nitrogen penetration, since nitrogen is characterized by low mobility in nitride compounds [8].

The phase composition of the surface of steel samples with preliminary heat treatment and heated by Mo ions, neither before nor after nitriding, practically do not differ from each other. Hence, it follows that the phase modification, which occurs due to the temperature heating of the surface layer of the steel as a result of a more energetic action by molybdenum, does not occur. Significant differences in the phase composition of nitrided steel occur only in the case of preliminary surface modification with titanium as a result of ion bombardment.

One more factor should be noted, which is important when choosing a method for preliminary surface preparation to obtain maximum nitriding depths. In the case of ion bombardment of both $\mathrm{Ti}$ and Mo as a result of sputtering on the steel surface, besides the relief morphology, also "pit" formations are observed in the places where dislocations emerge on the surface, [9]. However, when bombarded with heavy Mo ions, such "pits" are $\sim 2$ times larger than when bombarded with Ti ions, which, apparently, enhances the efficiency of nitrogen diffusion through dislocations and leads to increased nitriding depths.

\section{CONCLUSIONS}

1. The influence of the ion-plasma modification of the surface during its bombardment with $\mathrm{Ti}$ and Mo ions, used for heating elements, on the depth of the steel hardened layer by nitriding has been determined.

2. The more developed relief morphology, created by bombarding Mo ions, and its pit formations, contribute to an increase in the efficiency of nitrogen penetration and, accordingly, increase the depth of the hardened layer by nitriding by about $30 \%$.

3. Titanium, which is located on the surface of steel after ion bombardment, performs functions that restrict the movement of nitrogen diffusing directionally into the depth: retaining nitrogen due to saturation of the surface layers of steel, as well as blocking its penetration through the formation of nitride compounds of the $\mathrm{Ti}_{\mathrm{x}} \mathrm{N}$ type.

4. To obtain the greatest depths of hardening as a result of complex ion-plasma treatment of samples for preliminary heating of the surface, it is advisable to use bombardment with heavy metal ions such as Mo ions.

\section{REFERENCES}

1. Y. Sun and T. Bell. Combined Plasma Nitriding and PVD Treatments // Transaction Inst. of Met. Finishing. 1992, v. 70(1), p. 38-44.

2. L. Escalada, J. Lutz, S.P. Brühl, M. Fazio, A. Márquez, S. Mändl, D. Manova, S.N. Simison. Microstructure and corrosion behavior of AISI $316 \mathrm{~L}$ duplex treated by means of ion nitriding and plasma based ion implantation and deposition // Surface \& Coatings Technology. 2013, v. 223, p. 41-46.

3. А.А. Андреев, В.В. Кунченко, Л.П. Саблев, В.М. Шулаев. Дуплексная обработка инструментальных сталей в вакууме // Оборудование $и$ технологии термической обработки металлов и сплавов в машиностроении. Харьков: ННЦ ХФТИ, 2001, ч. 2, с. 48-56.

4. В.А. Белоус, М.Г. Ищенко, Г.И. Ищенко, Ю.А. Заднепровский, Н.С. Ломино. Использование комплексной ионно-плазменной обработки рабочих поверхностей шарнирных соединений для повышения их эксплуатационного ресурса // Сб. материалов 12-й Международной научнотехнической конференциии «Взаимодействие излучения с твердым телом». Беларусь, Минск, 19-22 сентября 2017 г., с. 367-370.

5. Л.П. Саблев, Н.С. Ломино, Р.И. Ступак, А.А. Андреев, А.М. Чикрыжов. Двухступенчатый вакуумно-дуговой разряд: характеристики и методы создания // Оборудование $u$ технологии термической обработки металлов и сплавов. Харьков: ННЦ ХФТИ, 2005, ч. 2, с. 159-169.

6. Anders Andre. Catodic Arcs. Springer Science + Business Media. LLC, 2008, p. 514.

7. В.А. Белоус, И.Г. Ермоленко, Ю.А. Заднепровский, Н.С. Ломино. О распределении концентраций азота по глубине стали при комплексном методе упрочнения поверхности // Журнал физики и инженерии поверхности. Харьков, 2016, т. 1, №2, c. 158-161.

8. Ю.М. Лахтин, Я.Д. Коган, Г.И. Шпис и др. Теория и технология азотирования. М.: «Металлургия», 1991, 320 с.

9. В.А. Белоус, Ю.А. Заднепровский, Н.С. Ломино, И.С. Домнич, С.В. Худяков. Влияние обработки поверхности стали бомбардирующими ионами на ее твердость и глубину азотирования // Mатериаль 13-й Международной научно-технической конференции «Взаимодействие излучения $c$ твердым телом». Беларусь, Минск, 30 сентября 3 октября 2019 г., с. 213-217. 


\title{
ВЛИЯНИЕ ПРЕДВАРИТЕЛЬНОГО НАГРЕВА ПОВЕРХНОСТИ НА ГЛУБИНУ АЗОТИРОВАНИЯ СТАЛИ 25Х1М1Ф ПРИ КОМПЛЕКСНОЙ ИОННО-ПЛАЗМЕННОЙ ОБРАБОТКЕ
}

\author{
В.А. Белоус, Ю.А. Заднепровский, И.С. Домнич
}

В технологии азотирования деталей используют различные способы их термического нагрева. Наиболее простым способом нагрева при ионно-плазменном азотировании является нагрев с помощью бомбардировки поверхности сначала газовыми ионами низких энергий, а затем ионами металлов с энергиями до нескольких килоэлектронвольт. Детали, подвергнутые ионной бомбардировке, имеют очищенную от загрязнений и развитую поверхность, способствующую диффузии азота в глубину металла при азотировании. В работе исследовано влияние различных способов предварительного нагрева на глубину азотирования при комплексной ионно-плазменной технологии упрочнения стали 25X1М1Ф. Для диагностики изменений, происходящих на поверхности образцов и на расстоянии от нее в глубину металла, применяли сканирующий электронный микроскоп JSM 7000-1F, оснащенный приставкой рентгеноспектрального энергодисперсионного микроанализа, и производили измерения твердости с помощью прибора Nanoindentor G200. Предварительный нагрев образцов осуществлялся как с использованием бомбардировки ионами Ті или Мо, так и без ее непосредственного воздействия на нагреваемую поверхность. В эксперименте наблюдаются различия по глубине упрочнения азотированного слоя стали при ее нагреве разными способами. При бомбардировке ионами Мо получены наибольшие глубины упрочнения по сравнению с другими условиями предварительного нагрева. Показано, что эти различия связаны с особенностями морфологии поверхности стали, сформированной в результате распылительных процессов. Образование нитридных соединений в ее поверхностном слое может служить барьером, замедляющим проникновение азота в металл. Показано, что при комплексной обработке в процессе осаждения нитридного покрытия на поверхность азотированной стали происходит дополнительное увеличение глубины упрочнения азотированного слоя.

\section{ВПЛИВ ПОПЕРЕДНЬОГО НАГРІВУ ПОВЕРХНІ НА ГЛИБИНУ АЗОТУВАННЯ СТАЛІ 25Х1М1Ф ПРИ КОМПЛЕКСНІЙ ІОННО-ПЛАЗМОВІЙ ОБРОБЦІ}

\section{В.А. Білоус, Ю.О. Задніпровський, І.С. Домніч}

В технології азотування деталей використовують різні способи їх термічного нагріву. Найбільш простим способом нагріву при іонно-плазмовому азотуванні $\epsilon$ нагрів за допомогою бомбардування поверхні спочатку газовими іонами низьких енергій, а потім іонами металів з енергіями до декількох кілоелектронвольт. Деталі, які піддавалися іонному бомбардуванню, мають очищену від забруднень і розвинену поверхню, що сприяє дифузії азоту вглиб металу при азотуванні. В роботі досліджено вплив різних способів попереднього нагріву на глибини азотування при комплексній іонно-плазмовій технології зміцнення сталі 25Х1М1Ф. Для діагностики змін, що відбуваються на поверхні зразків і на відстані від неї вглиб металу, застосовували скануючий електронний мікроскоп JSM 7000-1F, оснащений приставкою рентгеноспектрального енергодисперсійного мікроаналізу, і проводили вимірювання твердості за допомогою приладу Nanoindentor G200. Попередній нагрів зразків здійснювався як з використанням бомбардування іонами Ті або Мо, так і без його безпосереднього впливу на поверхню, що нагрівалася. В експерименті спостерігаються відмінності за глибиною зміцнення азотованого шару сталі при іiі нагріванні різними способами. При бомбардуванні іонами Мо отримані найбільші глибини зміцнення в порівнянні з іншими умовами попереднього нагрівання. Показано, що ці відмінності пов'язані з особливостями морфології поверхні сталі, сформованої в результаті розпилювальних процесів. Утворення нітридних з'єднань в її поверхневому шарі може служити бар'єром, що уповільнює проникнення азоту в метал. Показано, що при комплексній обробці в процесі осадження нітридних покриттів на поверхню азотованої сталі відбувається додаткове збільшення глибини зміцнення азотованого шару. 